\title{
Sourcing Technological Knowledge Through Foreign Inward Licensing to Boost the Performance of Indian Firms: The Contingent Effects of Internal R\&D and Business Group Affiliation
}

\author{
Stefano Elia ${ }^{1} \cdot$ Surender Munjal ${ }^{2}$ D $\cdot$ Vittoria G. Scalera ${ }^{3}$
}

Received: 28 May 2019 / Revised: 27 May 2020 / Accepted: 8 June 2020 / Published online: 30 June 2020

(c) The Author(s) 2020

\begin{abstract}
Sourcing technological knowledge from abroad is becoming a popular strategy among emerging market firms (EMFs). Combining the Knowledge-Based View and the Resource Dependence Theory, we argue that augmenting technological knowledge through foreign licensing enables EMFs to access state-of-the-art technological knowledge, reduce operational costs and risks associated to the innovation process, and develop a knowledge-based competitive advantage, ultimately boosting their financial performance. Using data about Indian firms observed from 2001 to 2013, we find that firms with a higher share of foreign inward technology licenses report better financial performance. However, the positive impact of technological knowledge accessed through inward licensing on firm performance is contingent upon: (1) the internal knowledge developed through R\&D activity, and (2) the affiliation with business groups. While Indian firms with higher level of internal R\&D are able to better leverage the value of foreign technological knowledge, thus reaching higher performance, firms affiliated to business groups gain fewer benefits from licensed foreign technological knowledge than non-business-group affiliated firms.
\end{abstract}

Keywords Emerging market firms · Foreign inward technology licensing · Financial performance $\cdot$ Business group $\cdot$ Knowledge-based view $\cdot$ Resource dependence theory

Surender Munjal

smu@lubs.leeds.ac.uk

1 School of Management, Department of Management Engineering, Politecnico di Milano, Milan, Italy

2 James E Lynch India and South Asia Business Centre, Centre for International Business, Leeds University Business School, University of Leeds, Leeds, UK

3 University of Amsterdam Business School, University of Amsterdam, Amsterdam, The Netherlands 


\section{Introduction}

Rapid evolution and rising presence of emerging market firms (EMFs) in an array of global industries have attracted significant attention. Scholars (e.g., Athreye and Cantwell 2007; Awate et al. 2015; Cuervo-Cazurra and Genc 2008; Kumaraswamy et al. 2012; Lall 2003; Luo and Tung 2007) attribute sourcing of foreign technological knowledge as the key factor behind the EMFs' rapid global success, because it initiates an inevitable process of technological upgrading. Foreign technological knowledge fosters the catching-up of EMFs with their global peers (Awate et al. 2012, 2015; Cui et al. 2016; Liu and Zou 2008; Perri et al. 2016), accelerates the internationalization process (Buckley et al. 2016a, b; Thite et al. 2016), and increases the innovative performance (Cassiman and Veugelers 2006). However, academic understanding of the influence of foreign technological knowledge on the EMFs' financial performance is still limited (Kafouros and Forsans 2012; Tsai and Wang 2008), yet it is fundamental to comprehend the ultimate effect of this widely used technological knowledge sourcing strategies.

Additionally, previous research has mainly analyzed the cross-border technological knowledge sourcing by EMFs through intensive and proactive internationalization strategies, such as foreign direct investments (FDI) (Pavlínek 2018; Scalera et al. 2020). However, little attention has been devoted to alternative forms of technological knowledge sourcing strategies, such as inward licensing, which are also potentially beneficial, but most importantly faster and easier to be implemented, and comparatively less expensive (e.g., Sikimic et al. 2016). Addressing this gap, in this paper we focus on EMFs' strategy to use inward licensing to access foreign technological knowledge, and its impact on their financial performance. Therefore, the core research question of our paper is: How does foreign technological knowledge acquired through inward licenses affect the financial performance of EMFs?

To answer our research question, we rely on the Knowledge-based view (KBV) of the firm (Grant 1991, 1996; Kogut and Zander 1992), which proposes that firm performance is a function of knowledge amassed by the firm, and the Resource Dependence Theory (RDT), which suggests that firms maximize their economic power by controlling critical external resources (Pfeffer and Salancik 1978). Combining these theories, we posit a general positive contribution of technological knowledge acquired through inward licensing on EMFs' performance.

We extend the analysis by distinguishing between the domestic and international origin of the licensed technological knowledge, and we argue that foreign inward licenses may be more beneficial to firm performance than domestic inward licenses. Indeed, the former enables the access to more specialized, diverse and advanced technological knowledge than the latter, thus potentially embodying a higher prospect to the firm's sustainable competitive advantage and its technological catchingup process (McGrath et al. 1996; Winter and Szulanski 2001).

However, we also expect that the impact of the advanced technological knowledge sourced via foreign inward licenses can be inequitable among EMFs. Ceteris paribus, the effect is contingent upon firms' structure and the organization of their internal resources. Indeed, the theoretical underpinning for a plausible answer to our 
main research question depends upon the fit between the technological knowledge acquired through licenses and the endowment of technological knowledge held by the EMF, either directly developed within the firm or available via the shared control with other firms. More specifically, we suggest that the positive impact of foreign inward licenses is affected by (1) the firm's knowledge base developed internally through R\&D activity, and (2) the firm's access to additional resources available within the business group's network.

For developing our first argument, we build upon the literature suggesting that internal R\&D enhances the firm's ability to understand, absorb and employ external technological knowledge (Cohen and Levinthal 1990). Given the relatively lower technological knowledge base of EMFs, we argue that the combination of internal R\&D with the external technological knowledge sourced through inward licenses from abroad triggers a positive interaction mechanism that boosts the EMFs' financial performance, by making the technological catch-up process more effective and efficient. It offers the possibility to convert the foreign technological knowledge more rapidly and efficiently into commercial products and services (Cohen and Levinthal 1990; Tsai and Wang 2008). Additionally, internal R\&D can complement the advanced and specialized knowledge sourced through foreign inward licensing, thus prompting the rise of more effective synergies and, hence, new competitive advantages (Cassiman and Veugelers 2006; Kogut and Zander 1992; Sapienza et al. 2005).

About the second contingent effect, we suggest that EMFs able to leverage the resources held by their broader corporate network, may also benefit from foreignsourced technological knowledge. However, EMFs affiliated to a business group, i.e., a set of legally independent firms bound together by formal and informal ties for taking coordinated action (Khanna and Rivkin 2001), may draw less benefits from technological knowledge accessed through inward licensing, as group affiliated firms can already pool a set of diversified resources, including proprietary technological knowledge, from their inter-group network (Buckley et al. 2014; Gulati 1998).

Our hypotheses, tested on a firm-level panel data set of Indian firms observed from 2001 to 2013 (source: Prowess), are confirmed by the empirical analysis and a number of additional robustness checks. Indeed, foreign inward license turns out to have a positive impact on performance, being its effect amplified by internal R\&D. However, business-group affiliated firms exhibit a less positive performance when sourcing technology through foreign inward licenses.

Finally, our analysis, focused on Indian EMFs, provides significant implications for managerial decision making and theoretical development which can be vouched by testing our propositions in other emerging countries' contexts. First, it sheds light on the strategic role of foreign inward licensing as an alternative channel to source technological knowledge and foster EMFs' knowledge-based competitive advantage. Second, it extends the literature on technology licensing by focusing on its effect on firm performance distinguishing between the domestic and foreign origin of licenses, adding to the existing evidence focusing primarily on the effect of innovative performance (e.g., Wang et al. 2013). Third, it extends the KBV by combining it with the RDT. It reveals how the performance of EMFs is directly affected not only by the firm's own resources, but also by the externally sourced technological knowledge, and how the utility of the latter is contingent upon both the firm internal R\&D 
and the group network resources. Fourth, it suggests that, on the one hand, managers of EMFs (especially the Indian ones) should consider the strategy of acquiring technological knowledge via inward foreign licenses to boost their financial performance, especially when combined with internal R\&D. On the other hand, managers of (Indian) EMFs belonging to business groups should explore the availability of alternative technological knowledge within their network of firms first, before looking for external resources through inward foreign technology licenses.

\section{Theoretical Framework and Hypotheses}

The KBV conceives the firm as an institution that generates, amasses and applies knowledge in order to create value (Eisenhardt and Santos 2002). It suggests that knowledge is a key resource, and heterogeneity in the knowledge base among firms leads to variation in their performance (Decarolis and Deeds 1999; Felin and Hesterly 2007; Grant 1996). In particular, firms adopt different entrepreneurial strategies to boost and sustain differentiation of their knowledge base (Galunic and Eisenhardt 1994), for instance, by developing knowledge-based resources internally through conducting own R\&D, or by sourcing knowledge externally.

In this respect, the extant literature recognizes the importance of technological knowledge for the success of EMFs. Technological knowledge (in a wider sense) refers to "both basic scientific knowledge right through to more applied and experimental development, design and prototype work, not just R\&D-based knowledge (although it does not cover more general managerial or marketing knowledge)" (Howells et al. 2003, p. 395). Nevertheless, constrained by the resources and time scarcity, the lack of a solid knowledge base and the need to strengthen their core competencies, EMFs often resort to the acquisition of technological knowledge from external sources (Ahuja and Katila 2001; Awate et al. 2015; Cui et al. 2016). This allows the EMF to reduce its R\&D costs, gestation time and uncertainties associated with the $R \& D$ projects while enhancing the degree of knowledge base of the firm (Chung and Yeaple 2008). This translates into higher economic rent and a better control over the 'new' knowledge generated through the combination of external and internal knowledge (Cassiman and Veugelers 2006; Kessler et al. 2000; Kogut and Zander 1992; Tsai and Wang 2008, 2009).

This view is fully supported by the RDT, which suggests that firms maximize their economic power by controlling critical external resources (Pfeffer and Salancik 1978). In this perspective, the access to external resources is conceived as a strategy to reduce the costs and uncertainty of developing new technological knowledge (Mowery 1988). Scholars suggest that inward licensing-a contractual agreement through which a licensee firm acquires the right to use technology (e.g., patents, trademarks) owned by another organization or individual, i.e., the licensor (Atuahene-Gima 1992; Howells et al. 2003) — as one of the most efficient modes to source technological resources needed by the firm for enhancing performance and building competitive advantages (Atuahene-Gima 1992, 1993; Chesbrough 2003; Deeds and Hill 1996; van de Vrande et al. 2011). 
This is likely to be true especially for EMFs. Inward licensing allows the firm to augment technological knowledge (Atuahene-Gima 1992; Contractor 1981; Chung and Yeaple 2008; Leone and Reichstein 2012; Wang et al. 2013) swiftly, legitimately and efficiently (Kotabe et al. 1996). It helps the EMF to be competitive and overcome latecomer disadvantages (Katrak 1990; Luo and Tung 2007; Pitkethly 2001), without having to invest massive capital or bear the risk and uncertainty associated with in-house development of technological knowledge (Tidd et al. 2001).

Scholars further emphasize the positive effects that inward technology licenses may exert, particularly when combined with internal R\&D (e.g., Kessler et al. 2000; Sikimic et al. 2016; Spencer 2003; Tsai and Wang 2008). However, most of the previous studies did not distinguish between the geographical origin of inward licenses, which in turn may trigger heterogeneous effects on performance. Exceptions are Tsai and Wang (2009) and Wang et al. (2013), who distinguish between foreign and domestic and find that the former has a more positive effect on innovative performance than the latter.

This distinction is likely to be particularly relevant in the case of EMFs, which, on average, are lagging behind and have more severe resource constraints than firms from advanced countries. Indeed, inward licensing provides EMFs with the possibility to acquire specific and advanced technological knowledge from across the globe, thus matching firms' requirements and complementing their internal resources in relatively short time (Buckley et al. 2016a; Tsai and Wang 2008). Hence, EMFs have the option to buy the technology either from domestic sources or from foreign sources (Wang et al. 2013), where domestic technology is likely to be less expensive than foreign technology and possibly, on average, inferior in comparison to the technology available from foreign markets (Fu et al. 2011; Levin and Barnard 2013; Scalera et al. 2018).

Nevertheless, little is known about the effect of foreign and domestic inward licenses on financial performance, which represents the ultimate proxy of value creation. The RDT itself assumes that the nature and the form of the environmental uncertainty and the organizational actions that lead to the acquisition of external resources (such as inward licencing) are universal across nations and societies (Steensma et al. 2000). This bias is probably due to the fact that this theoretical framework was developed mainly by American academics and tested within American samples. However, the application of such a theory without considering the broader and heterogeneous international context may be inappropriate (Steensma et al. 2000; Buckley and Munjal 2017). Therefore, extending the RDT through the application of a cross-border perspective from the EMFs point of view, we advance previous literature by exploring whether and how foreign (rather than domestic) inward licenses affect the EMFs' financial performance.

\subsection{Foreign Inward Technology Licensing and EMFs Performance}

There are many ways through which inward licensing can directly contribute to the firm financial performance. First, inward licensing allows EMFs to reduce the costs and risks associated with in-house development of technological knowledge, in terms of uncertain timing and outcome, and amount of resourced to be employed and developed. Second, it allows the EMF to cut the operational costs associated 
with production: access to modern technology, gained via inward licensing can quickly enable EMFs to replace their rudimentary, often labor intensive, production process with an advanced and automated one, thereby bestowing the economies of scale. Third, as a de facto strategy to outsource innovation, inward licensing can allow EMFs to focus on their internal core capabilities and compete effectively with peers by using different strategies at marketing front (Spear 2009; Young et al. 1996) as well as non-market front (Doh et al. 2014). In other words, securing advanced technology through licensing frees up managerial time and resources, which can be used, for instance, to secure clienteles and getting favorable treatment from government, to boost firm performance. Fourth, acquisition of the inward license may enable the firm to extend its product portfolio, differentiate and diversify its product offerings, create a niche in the market, and improve product quality. All these are likely to have a significant positive impact on sales and profitability.

These positive effects on financial performance are expected to be amplified for EMFs when the inward license is foreign, rather than domestic, as emerging economies' licensors are-on average-technologically less superior than those from advanced economies and foreign sources are likely to give EMFs access to real 'state of the artat technological knowledge (Chatterji and Manuel 1993). Moreover, innovative activities and knowledge resources differ across countries; thus, firms can increase their knowledge base by sourcing technological knowledge from foreign countries (Cantwell 1989; Chung and Yeaple 2008; Scalera et al. 2018). A growing body of research further argues that sourcing technological knowledge from abroad allows the EMF to break away the constraints associated with the use of domestically available technological knowledge (e.g., Aggarwal 2000; Deng 2009; Luo and Tung 2007). The use of foreign technological knowledge also allows the EMF to learn by reverse engineering (Duysters et al. 2009; Govindarajan and Ramamurti 2011; Thite et al. 2016; von Zedtwitz et al. 2015). It makes the firm more agile, flexible and diversified, and it increases its technological capabilities, which may have a direct positive effect on its performance (Chatterji 1996; London and Hart 2004; Malik and Kotabe 2009; Minagawa et al. 2007).

Furthermore, being able to participate in international innovation networks of foreign licensors empowers EMFs to gain access to more advanced innovation opportunities and opens up potential collaborations between network participants (Wang et al. 2013). Thus, EMFs focusing primarily on domestic technology licensing tend to have small ability to access the frontier technologies developed by more advanced competitors (Kafouros and Forsans 2012; Hsieh et al. 2018). Additionally, licensingin from abroad offers EMFs the possibility to access technological knowledge developed in specialized clusters or with specific location requirements, which exposes licensee EMFs to a wider array of diversified skills. As a result, EMFs can use such inputs to mix existing and more advanced components or processes to extend their product and technology portfolio (Levinthal and March 1993; Scalera et al. 2018).

Therefore, in the case of EMFs, sophisticated licensed technological knowledge sourced from abroad may foster a stronger knowledge-based competitive advantage and, hence, a more beneficial impact on performance than technological knowledge sourced domestically. Foreign technological knowledge enables the receiving EMFs to diversify the technological base and foster a gradual process of accumulation of advanced skilled and knowledge, not possible otherwise, which ultimately may 
culminate in the introduction of new products and processes (Wang et al. 2013). By widening the firm's product (or service) portfolio and by increasing the efficiency of internal (innovation and production) processes, it is likely that foreign technology in-licensing ultimately determine better financial performance and, at the same time, accelerate the EMF's pace of technology development that helps the firm in finding new and efficient ways to develop valuable products (Miller et al. 2007; Wang et al. 2013) while creating a productive R\&D environment (Fey and Birkinshaw 2005). Kafouros and Forsans (2012) and Hsieh et al. (2018) further argue that the use of foreign external technological resources, which shortens the time associated with the development of new (radical and incremental) product, may allow the firm to gain first-mover advantage, enhance problem-solving abilities and reach a privileged market position, which in turn is likely to result into a superior financial performance.

According to the above arguments, we claim that, other things being equal, EMFs leveraging more inward foreign licenses are likely to perform better than firms relying primarily on domestic licenses. Therefore, we hypothesize that:

Hypothesis 1: The financial performance of EMFs is positively affected by a larger share of foreign (rather than domestic) inward technological licenses.

\subsection{The Interaction Effect of Firm R\&D}

The internal $R \& D$ can play a critical role in enhancing the effect of externally sourced technology on the firm's performance. At its basic, the internal R\&D efforts contribute to the absorptive capacity (Cohen and Levinthal 1990; Kogut and Zander 1992), which enables the firm to identify valuable technologies available in the market, incorporate the underlying technological knowledge, and transform it into a commercial product or process. Thus, prior research generally concludes that internal R\&D provides the necessary conditions to unlock the positive effect of external technological knowledge on the firm performance, as it enables the firm to assimilate and integrate knowledge sourced from others (Cohen and Levinthal 1990). In the context of EMFs, internal R\&D provides the firm with the capabilities necessary to understand, disentangle and exploit advanced specialized knowledge sourced through inward foreign licensing, so to extract more value and obtain a stronger knowledge-based competitive advantage than a case with low or without in-house R\&D.

Unlike previous literature, our first hypothesis claims that foreign inward licenses may have a positive effect on financial performance per se, without necessarily being complemented with internal R\&D. Here, we posit that the combination of the external technical knowledge sourced through foreign licenses, and the internal R\&D can amplify the positive effect on financial performance through some specific mechanisms that go beyond the simple provision of the absorptive capacities. First, an optimal combination of internal and external knowledge and technologies can lead to early commercialization of the firm's offerings to the market, thereby enhancing the firm's performance and competitive position in the market (Arora et al. 2001; Chesbrough 2003). Second, sourcing technological knowledge from foreign licensing provides EMFs with the opportunity to learn, not only about the foreign technological knowledge but also about foreign markets and, hence, to reach potentially the 
commercialization of the products on an international (rather than only on a domestic) scale, thus providing superior advantages in terms of performance and an even stronger cross-border competitive advantage. Third, scholars suggest that the firm's internal R\&D can be planned and organized in a way to supplement, optimize and complement the externally sourced technological knowledge (Cassiman and Veugelers 2006; Chesbrough 2003; Frishammar et al. 2012) that can give birth to new synergies and boost the competitive advantage of the firm (Buckley et al. 2016a; Liu et al. 2014). We expect this process to be even more effective if the externally sourced technological knowledge is of superior quality, as it often happens (in the case of emerging countries) with foreign inward licenses.

Finally, studying a sample of Indian firms, Kafouros and Forsans (2012) show that integrating external technological knowledge with the internal knowledge base can unlock the EMF's innovativeness, which may have a direct influence on the firm's performance. Hsieh et al. (2018) confirm that the exposure to foreign external knowledge increases the opportunities to create valuable combinations with the internal knowledge owned by the company. Given the superior technological knowledge embedded by foreign licenses, the combination of internal R\&D with the latter might enable EMFs to trigger more innovation activities, thus amplifying the positive effect on performance.

Hence, we expect that EMFs with higher level of internal R\&D will be better able to leverage the external knowledge acquired through foreign in-licensing, thus leading to higher performance. Therefore, we propose the following second hypothesis:

Hypothesis 2: The effect of a larger share of foreign inward technological licenses on financial performance is more positive in EMFs with higher level of internal $R \& D$.

\subsection{The Interaction Effect of Business-Group Affiliation}

The extant literature provides evidence of the differentiation of financial performance of group affiliated firms against non-affiliated firms. Belenzon and Berkovitz (2010) synthesize the factors differentiating financial performance with the structure and organization of business groups. They suggest that large-scale and high diversification of group activities, availability of cheaper internal than external capital, and generation of knowledge spillovers from research activities within the network of groupaffiliated firms, all contribute towards better financial performance of firms affiliated to a business group in comparison to non-affiliate firms. Moreover, networking of firms affiliated to a business group offers them an exceptional opportunity to share $\mathrm{R} \& \mathrm{D}$ efforts, talented managers and engineers, and co-finance the generation of new intangible assets (e.g., intellectual property, such as patents and trademarks) and technological innovations (Chang and Hong 2000; Chang et al. 2006).

Chang and Hong (2000) provide evidence that the financial performance of business group affiliates is positively associated with the stock of intangible and financial resources of other firms in the same business group. As such, business group's affiliation allows the firm with the possibility of not only improving their own 
intangible assets, which have a direct positive effect on the firm's performance, but also of directly exploiting other affiliates' tangible and intangible resources.

Thus, we argue that group affiliation is also likely to affect the impact of external technological knowledge on the firm's performance. However, we contend that business group affiliated EMFs may benefit less from externally in-licensed foreign technological knowledge than non-business group affiliated firms. Our prime contention has a twofold rationale. First, business group affiliated EMFs are likely to develop better technological knowledge than non-business group affiliated firms, because they can access technological knowledge amassed by other firms within the group. This can marginalize (at least to some extent) the positive effect of foreign technological knowledge for business group affiliated EMFs. Second, the group's technological knowledge is likely to have been developed or acquired by other firms within the group for some other purposes. Thus, the knowledge accessed by the EMF from other firms within the group may not perfectly fit with the foreign technological knowledge acquired through licensing. Hence, the ownership and nature of group resources may hinder the complementarity effect of foreign technological knowledge sourced by EMFs. Therefore, we propose that the effect of foreign licenses is less positive in the case of business groups-affiliated EMFs. Hence our hypothesis is:

Hypothesis 3: The effect of a larger share of foreign technological inward licenses on financial performance is less positive in EMFs affiliated to business groups than in non-affiliated.

\section{Data and Methodology}

\subsection{Empirical Context}

Our empirical analysis relies on a sample of Indian firms. We find the Indian context particularly appropriate to test our theoretical framework and hypotheses for the following reasons. First, India's indigenous technological capabilities in technologyrelated industries are significant; however, many Indian firms still seek external technological resources overseas (Buckley et al. 2016c; Buckley and Munjal, 2017; Chittoor et al. 2009; Scalera et al. 2020). Second, with the introduction of New Patent Act in 2005 (followed by the National Intellectual Protection Rights Policy in 2016), India has strengthened its intellectual property law. In the new regime, firms are no longer allowed to do process patenting. This implies that Indian firms have to license/buy technological knowledge from an original vendor rather than using it just by re-engineering. Finally, Indian firms have scaled up their competitive advantages by accessing foreign technological knowledge (e.g., Aggarwal 2000; Kumaraswamy et al. 2012). Consequently, many Indian multinational enterprises (MNEs) have become world's leading firm in their respective industry, e.g., Tata Motors has produced 'Nano', the world's cheapest car, by accessing advanced automobile technology from Bosh; Suzlon became the fifth largest wind energy company by accessing technology from Sudwind and RE Power (Awate et al. 2012; Munjal et al. 2013). 
Even if the literature has mainly focused on the use of strategic asset-seeking FDI employed by Indian companies to acquire and develop new knowledge (Deng 2009; Luo and Tung 2007), the use of foreign technology licenses has been widely adopted by Indian firms for the same goal. A relevant example in the recent years is India's ISGEC Heavy Engineering Ltd., a leading engineering company that was successful in securing a competitive license from the US-based Fuel Tech Inc. for the selective non-catalytic reduction technology (Businesswire 2016).

Scholars (e.g., Awate et al. 2015; Lall 2000; Thite 2016) argue that for emerging countries, such as India, foreign technological knowledge is still a strategic resource because technological assets available in developed countries are comparatively more advanced than the technological resources available in developing countries. Recent studies suggest that EMFs internationalize their activities primarily driven by learning motivations, leveraging global markets to gain knowledge and innovative ideas unavailable at home (Buckley et al. 2016a, b; Chittoor et al. 2015; Munjal et al. 2019; Pereira et al. 2019). This has favored the catch-up process of Indian firms that is evolving at a rapid pace but not yet completed.

\subsection{Data}

Data for our empirical examination are drawn from Prowess. This database, prepared by the Centre for Monitoring Indian Economy, provides background information and financial data on Indian firms listed in the Indian stock exchange. Prowess is a popular database which has been used in many studies on Indian firms (e.g., Bhaumik et al. 2010; Buckley et al. 2016a, b, c; Chittoor et al. 2009, 2015; Gubbi et al. 2010; Stucchi et al. 2015). It is argued that Prowess is "substantially richer" than other similar databases, such as 'Worldscope', which is the widely used firm level global database (Oura et al. 2009 p. 4).

Due to missing values of our variables of interest, the final sample employed for the baseline models is an unbalanced panel data set observing $303^{1}$ Indian firms operating in manufacturing and service industries over from the period 2001-2013, with a final number of observations equal to 2300. Firms belong to a large range of industries, from agriculture, forestry and fishing sector to administrative and support service activities.

\footnotetext{
${ }^{1}$ Given that the variable accounting for inward licensing is the main responsible for the drop of observations due to the high amount of missing values, we counted the number of firms for which all the other variables were fully available, and we found that they are equal to 1450 . Therefore, we performed a Chi Square test in order to verify whether our sample of 303 firms is representative of the larger sample (i.e., 1450 firms) that would be available without our key explicative variable. We found that the null hypotheses stating that our sample is representative cannot be rejected as regards the size (SMEs vs. large firms), the industries (manufacturing vs. services) and the type (private vs. public) of firms, using $5 \%$ as level of significance.
} 


\subsection{Variables}

The dependent variable is Financial Performance, which is measured through the Return on Assets (ROA) for each company in each year. This is a very popular proxy of firm's performance in both strategic and managerial literature, as it accounts for the efficiency with which a firm employs its assets base (e.g., Roberts and Dowling 2002).

Our main explicative variable is Foreign Licenses, which is measured as the ratio between the royalties paid to foreign licensors, and the total royalties paid by Indian firms to acquire licenses for technical knowledge. Following the first hypothesis, we expect a positive relationship between this variable and the performance measure. The average value of the share of foreign licenses is about $43 \%$, being slightly higher for Indian firms not affiliated $(44.4 \%)$ than for Indian firms affiliated $(42.8 \%)$ to business groups. This preliminary evidence confirms that Indian firms often recur to foreign licenses when adopting a knowledge sourcing strategy through inward licensing.

In order to test our two interaction effects referred to hypothesis 2 and hypothesis 3, we use Firm $R \& D$ and Business Group, respectively, as moderating variables. Firm $R \& D$ is measured as the total expenditures in R\&D and accounts for the in-house technological base of each Indian firm (Tsai and Wang 2008). Business Group is a dummy taking the value of 1 if the ownership of Indian firms belongs to a corporate group and zero otherwise. Both Firm R\&D and Business Group are expected to boost the positive effect of Foreign Licenses on Financial Performance, as suggested by hypothesis 2 and hypothesis 3 .

We finally apply a set of control variables. First, we control for Intangible Assets Share, which is measured as the ratio between the intangible assets (which include the values of the brand, goodwill and patents) and the total assets held by the company, as resulting from the balance sheet. Second, we control for firm heterogeneity in terms of its experience, size and the type of company through the variables Age, Size and Public Company, respectively. The age of the firm is accounted for through the year in which the company was established; the size is represented by the firm's total assets; and a dummy variable accounts for public status of companies (equals 1 if company is public, otherwise zero). In addition, we introduced industry dummies (one for each of the 9 NIC codes at the one-digit level) and time dummies (one for each of the 12 years considered), in order to control for industry and year fixed effects.

\subsection{Empirical Models}

The final equation model is, hence, the following:

$$
\begin{aligned}
\text { Financial Performance }_{i}^{t}= & \alpha_{i}+\beta_{1} \text { Foreign Licences }_{i}^{t-1}+\beta_{2} \text { Firm R\&D }_{i}^{t-1} \\
& +\beta_{3} \text { Business Group }_{i}+\beta_{4} \text { Controls }_{i}^{t-1}+\varepsilon_{i}^{t}
\end{aligned}
$$


Table 1 Correlation matrix and descriptive statistics of the dependent and explicative variables

(1)

(2)

(3)

(4)

(5)

(6)

(7)

\begin{tabular}{llrrrrrrrrr} 
(1) & Financial performance & 1.000 & & & & & & & \\
(2) & Foreign license & -0.002 & 1.000 & & & & & & \\
(3) & Firm R\&D & 0.022 & -0.045 & 1.000 & & & & & \\
(4) & Business group & 0.044 & -0.039 & -0.074 & 1.000 & & & & \\
(5) & Intangible assets & 0.082 & 0.047 & 0.051 & -0.013 & 1.000 & & & \\
(6) & Age & 0.059 & 0.043 & -0.013 & 0.015 & 0.089 & 1.000 & & \\
(7) & Size & -0.318 & 0.122 & 0.207 & -0.133 & -0.146 & -0.157 & 1.000 & \\
(8) & Public company & 0.047 & -0.034 & 0.030 & 0.025 & -0.026 & -0.299 & 0.017 & 1.000 \\
& Observations & 2300 & 2300 & 2300 & 2300 & 2300 & 2300 & 2300 & 2300 \\
& Mean & 0.132 & 0.454 & 0.131 & 0.458 & 0.007 & -1.247 & 1.514 & 0.926 \\
& SD & 0.101 & 0.247 & 1.581 & 0.498 & 0.024 & 1.563 & 2.509 & 0.262 \\
& Min & -0.639 & 0.000 & -0.137 & 0.000 & 0.000 & -6.955 & -0.126 & 0.000 \\
& Max & 1.201 & 1.000 & 29.265 & 1.000 & 0.502 & 1.276 & 29.341 & 1.000 \\
\hline
\end{tabular}

where $t$ is the year and $i$ represents each Indian firm included in the sample. To test the hypothesis 2 and hypothesis 3 we interacted the variable Foreign License with the variable Firm $R \& D$ and Business Group, respectively.

We lagged the time variant explicative and control variables of 1 year to limit reverse causality issues. In addition, we also standardized the variables Firm $R \& D$, Age and Size, in order to normalize the different scales of these variables. Table 1 provides the correlation matrix and descriptive statistics of our dependent and explicative variables.

As regards the methodology, due to the panel nature of our database with a continuous dependent variable, we performed a Feasible Generalized Least Square (FGLS) model by adopting a heteroskedastic error structure. This model produces a matrix-weighted average of the 'random effect' and 'within' results and, unlike the Generalized Least Square, makes use of an estimate of a variance-covariance matrix instead of assuming that it is known, producing efficient estimates and unbiased standard errors (Petersen 2009).

\section{Results}

The outcome of our analysis is displayed in Table 2. Columns 1 shows the results of the baseline model while columns 2, 3 and 4 show the results when introducing the interactions effects ( $R \& D$, business groups and both, respectively).

As regards the control variables, model 1, which exhibits the baseline results, shows that Intangible Assets Share turns out to be positive but not significant. As far as Age and Size are concerned, the negative and significant coefficients $(\mathrm{p}<0.01)$ provide evidence that older and smaller firms tend to perform better than younger and larger firms, respectively. At the same time, the variable Public Companies exhibits a strong and positive association with the dependent 


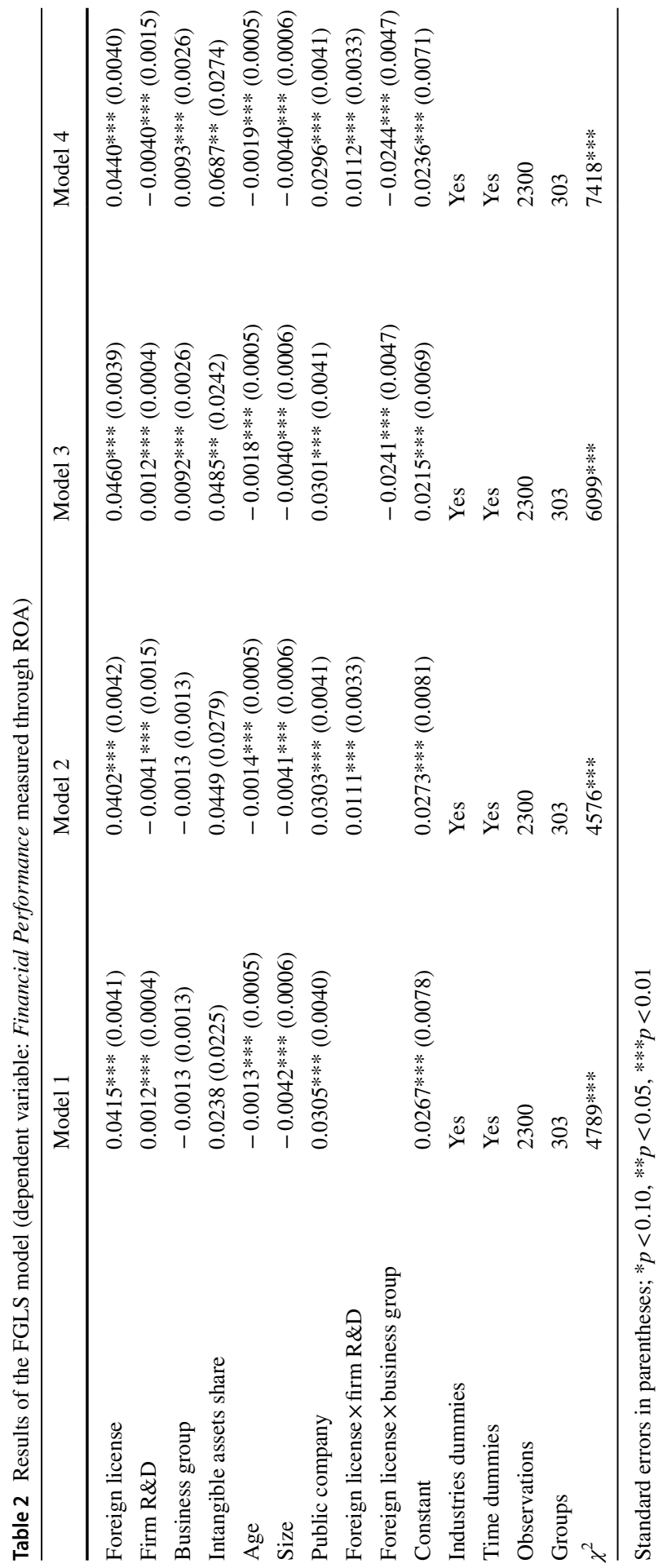




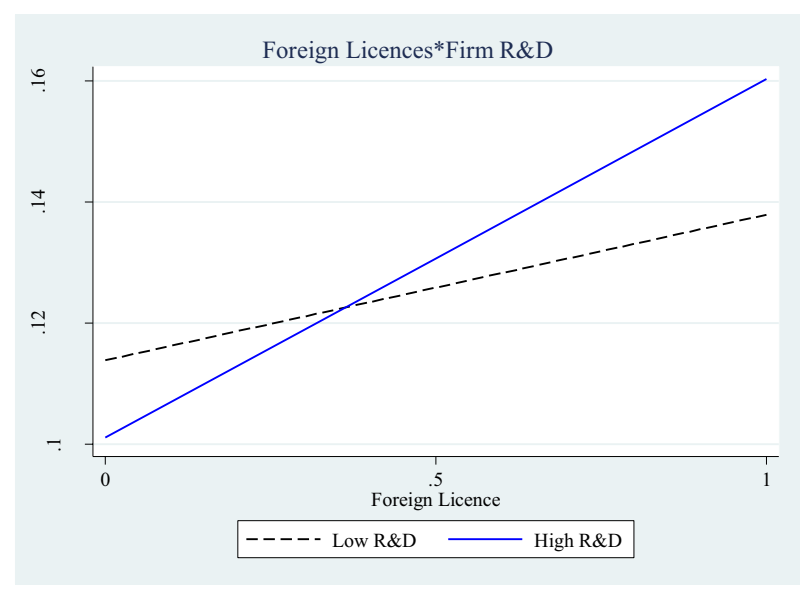

Fig. 1 The effect of Firm R\&D to the relationship between Foreign License and Financial performance (measured through ROA)

variable $(\mathrm{p}<0.01)$, probably due to the larger financial resources that are available to public with respect to private companies for high-return investments.

As regards our explicative variables, model 1 shows that Foreign License exhibits a positive and significant coefficient $(\mathrm{p}<0.01)$, thus confirming hypothesis 1, i.e., foreign inward licensing has a positive impact on the firm's financial performance. The variable Firm $R \& D$ also displays a positive and significant coefficient $(\mathrm{p}<0.01)$, so confirming that investing in $R \& D$ has a positive effect on firm performance. Additionally, columns 2 and 4 show that the interaction between Firm $R \& D$ and Foreign Licenses is positive and strongly significant $(\mathrm{p}<0.01)$, thus fully confirming our hypothesis 2 . Further, in order to offer a better interpretation of this interaction effect and to gain more insights into this latter hypothesis, we plotted the results of column 2 by using the coefficient estimates technique (Zelner 2009). Figure 1 displays that firms with higher (i.e., mean + standard deviation) R\&D investments perform better at growing levels of foreign licenses, compared to firm with relatively lower (i.e., mean - standard deviation) R\&D investments.

Finally, the variable Business Group is not statistically significant in model 1. Moreover, columns 3 and 4 show that the interaction between Foreign License and Business Group is negative and significant $(\mathrm{p}<0.01)$, thus confirming that business groups gain less from foreign licenses as suggested by our hypothesis 3. As done for the above interaction terms, we again plotted the interaction term of column 3. Figure 2 shows that the negative sign means that Foreign License has a less positive effect on the performance of business groups with respect to non-business groups, as shown by the smaller positive slope of the line associated to business-group affiliates. 


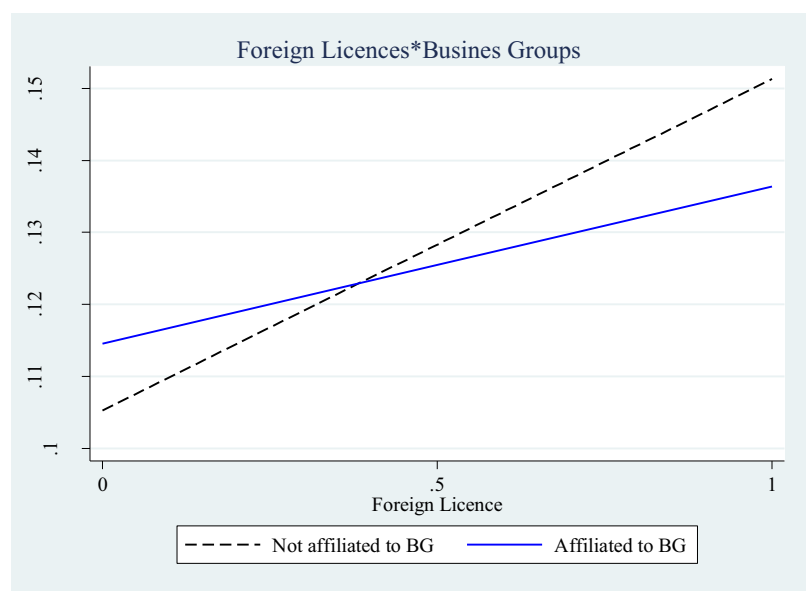

Fig. 2 The effect of business-group affiliation to the relationship between Foreign License and Financial performance (measured through ROA)

\subsection{Robustness Checks and Additional Evidence}

In order to provide additional evidence and to check whether our results are robust to different model specifications, we provide a number of further tests.

First, to check whether our main results are driven by the specific dependent variable used to measure financial performance, we replicate the main model using EBITDA (i.e., earnings before interest, tax, depreciation, and amortization) as an alternative dependent variable. This proxy has been identified as one of the main indicators reflecting the financial performance of the firms (e.g., Baier et al. 2008; Carr and Pearson 2002). The main advantage of this indicator is that it allows washing out the distortions arising from the selection of alternative asset depreciation schedules, from the specificity of the Indian tax regime and from the different strategic choices concerning the use of the financial leverage. Table 3, which displays the results when using EBITDA as a proxy for financial performance, fully confirms hypothesis 1 , hypothesis 2 and hypothesis 3 .

Second, in order to rule out endogeneity and omitted variable issues, we performed a set of alternative models. On the one hand, we employ a 2SLS analysis to control for the reverse causality issue, using as instruments the total amount of export and the total amount of outward FDI, both related to the (main) industry to which each EMF belongs to. We expect, indeed, these instruments to be correlated with the amount of foreign licenses acquired by each firm, since both these variables reflect the extent to which each industry is open to the international markets (through export, outward FDI or inward licenses). At the same time, export and outward FDI of whole industry is likely not to affect directly the performance of each specific firm. On the other hand, we run two regressions using the 2- and 3-year lags of the explicative and control variables, in order to minimize the possibility that the level of performance affects the acquisition of foreign licenses (rather than vice 


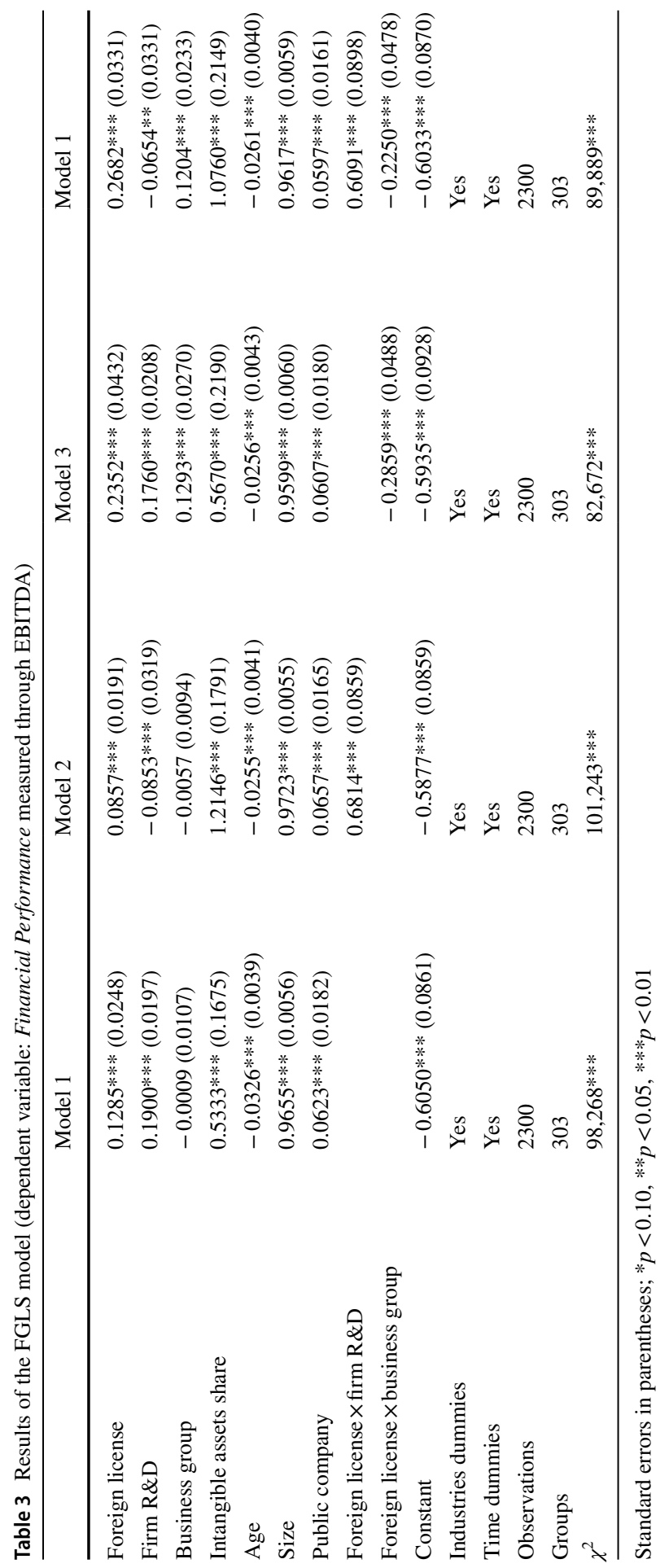


Table 4 Results of the 2-SLS (column 1), 2-year lag (column 2), 3-year lag (column 2) and fixed-effects (column 4) models (dependent variable: Financial Performance measured through ROA)

2-SLS Lag $2 \quad$ Lag $3 \quad$ Fixed-effects
(1)
(2)
(3)
(4)

\begin{tabular}{|c|c|c|c|c|}
\hline Foreign licence & $0.153 * *(2.22)$ & - & - & $0.032 * * *(2.96)$ \\
\hline Foreign licence lag 2 & & $0.029 * * *(6.88)$ & - & \\
\hline Foreign licence lag 3 & - & - & $0.020 * * *(4.86)$ & - \\
\hline Firm R\&D & $0.002(1.16)$ & - & & $-0.000(-0.80)$ \\
\hline Firm R\&D lag 2 & - & $0.001 *(1.79)$ & - & - \\
\hline Firm R\&D lag 3 & - & & $0.001 * *(2.03)$ & - \\
\hline Business group & $-0.000(-0.03)$ & $-0.002 *(-1.70)$ & $-0.001(-0.52)$ & - \\
\hline Intangible assets share & $-0.058(-0.64)$ & - & - & $-0.093(-0.46)$ \\
\hline $\begin{array}{l}\text { Intangible assets share } \\
\text { lag } 2\end{array}$ & - & $-0.005(-0.46)$ & - & - \\
\hline $\begin{array}{l}\text { Intangible assets share } \\
\text { lag } 3\end{array}$ & - & - & $0.025(0.57)$ & - \\
\hline Age & $-0.004(-1.18)$ & $-0.002 * * *(-4.73)$ & $-0.002 * * *(-3.51)$ & - \\
\hline Size & $-0.005(-1.34)$ & - & - & $0.003(1.57)$ \\
\hline Size lag 2 & - & $-0.004^{* * *}(-6.36)$ & - & - \\
\hline Size lag 3 & - & - & $-0.005 * * *(-6.41)$ & - \\
\hline Public company & $0.026(1.61)$ & $0.036^{* * *}(9.46)$ & $0.051 * * *(11.64)$ & - \\
\hline Constant & $-0.060(-0.71)$ & $0.028 * * *(3.52)$ & $0.017 * *(2.02)$ & $0.083 * * *(8.38)$ \\
\hline Industries dummies & Yes & Yes & Yes & No \\
\hline Time dummies & Yes & Yes & Yes & Yes \\
\hline Number of groups & 303 & 285 & 263 & 303 \\
\hline Number of observations & 2300 & 2040 & 1792 & 2300 \\
\hline$\chi^{2}$ & $106.542 * * *$ & $5292.954 * * *$ & $4090.097^{* * *}$ & - \\
\hline F-Test & - & - & - & $5.022 * * *$ \\
\hline
\end{tabular}

Standard errors in parentheses; $* p<0.10, * * p<0.05, * * * p<0.01$

versa). Finally, we test our baseline equation using a fixed-effect model, which enables to solve the problem of potential unobservable variables at firm-level, providing us with more efficient estimation of regression parameters (Green 1997; Maddala 1993). Table 4 reports the results of the baseline regressions after applying the 2SLS model (column 1), the 2- and 3-year lags (columns 2 and 3, respectively), and the fixed effects model (column 4), using ROA as a dependent variable. The positive and significant effect of the variable Foreign Licenses is always confirmed across all the four columns. ${ }^{2}$

Third, as the dependent variable of the main model, i.e., ROA, may be influenced by the previous year firm's performance, we replicated the four models described in

\footnotetext{
${ }^{2}$ To address the endogeneity issue, we also performed an F-test, by the means of which we cannot reject the null hypotheses that the three lagged coefficients of ROA are jointly statistically different from zero (Prob. $>\mathrm{F}=0.3311$ ) when the dependent variables is Foreign License.
} 
Sect. 3.4 including the autoregressive component of ROA among the regressors. Results (which are available upon requests) are in line with the evidence shown in Table 2.

Fourth, as we are interested in the relationship between the acquisition of foreign technological licenses and financial performance, we should exclude other possible driving effects related to the international activities of Indian firms (e.g., Bernard and Jensen 1999, 2004). Therefore, we run the baseline models controlling for firm export activities in order to capture the benefits that are typically associated to foreign export. By the means of the additional control variable Foreign Export, computed as the share between foreign export and total sales at firm-level, we took into consideration the international business activity of Indian firms. Results (which are available upon request) are in line with the evidence shown in Table 2.

Fifth, as Prowess includes both domestic and foreign companies located in India, we re-estimated our baseline models on the sub-sample of companies majority-owned by Indian investors, so that we can more clearly distinguish between foreign (non-Indian) and domestic (Indian) technology licenses. Results (which are available upon request) are in line with the evidence shown in Table 2.

Sixth, despite the large availability of data provided by Prowess database, we noticed that the information concerning the inward (foreign or domestic) licenses, which is our key explanatory variable, is either a positive (i.e., $>0$ ) or a missing value. Therefore, there might be the possibility that the unavailable values are not 'missing at random', i.e., that the probability that the information concerning the inward licenses is missing is not unrelated to the value of the inward license itself. In other words, it is likely that companies that acquire licenses display the value of the royalties paid, while companies that do not rely on inward licensing do not display the zero, thus resulting in a missing value. This means that the probability of having a missing value is likely to be larger in the subgroup of companies with zero royalties than in the subgroup of companies with nonzero royalties. When data are not missing at random, the missing-data mechanism needs to be modeled to get good parameters of the estimates and avoid inconsistent estimators. To test for a potential bias in our estimations, we use the procedure developed by Semykina and Wooldridge (2010), as used in other studies in management and innovation facing similar issues (e.g., Colombo et al. 2014; Grilli and Murtinu 2015). More specifically, we computed a first-stage model where the dependent variable, Inward License, is a dummy taking the value of 1 when companies display the value of the royalties paid to external suppliers for technological licenses, and zero if this value is missing (source: Prowess database). We then calculated an inverse Mills' ratio (IMR) variable computed from the first stage, in order to control for the unobserved factors that explain the selection of inward licensing as knowledge sourcing strategy. The IMR was then included as control in the baseline models. We found the absence of statistical significance of the IMR coefficient, reassuring us that selection bias does not significantly affect our results (the table with results is available upon request). 


\section{Discussion}

Our study provides new insights about the influence of external technological knowledge sourced through licenses on financial performance within the context of EMFs. It shows that the use of a higher share of foreign licenses, on average, renders a positive impact on the EMF's financial performance. This confirms prior research, which suggests that foreign technological knowledge yields superior technological knowledge than domestic licenses, thus contributing toward the development of a superior knowledge-based competitive advantage of EMFs (e.g., Deng 2009). The acquisition of inward licenses reduces the cost of the innovation process, and the cost associated with operations, by giving access to the state-of-the-art technological knowledge. Thereby, inward licenses directly contribute towards better financial performance. Moreover, better quality products, and diversity in the firm product portfolio achieved due to foreign technological knowledge boost revenues, which ultimately results in enhanced firm financial performance.

We also provide evidence that the firm's internal R\&D significantly affects the relationship between foreign licensing and financial performance. In line with prior research (Tsai and Wang 2008), we show that internal R\&D positively interacts with foreign in-licensed technology on the firm's financial performance. This effect is likely to materialize not only because of improvement in the absorptive capacity of the firms due to that internal R\&D, as traditionally suggested by the literature (Cohen and Levinthal 1990), but also due to other mechanisms, such as the broader international scope of the products commercialization, the stronger synergies and the more sophisticated innovation opportunities arising from the combination of the external technological knowledge of foreign licenses and the internal capabilities of R\&D activities.

However, unlike Tsai and Wang (2009), who already took into account the distinction between foreign and domestic licenses, and found a positive effect on (innovation) performance only through the moderation of $\mathrm{R} \& \mathrm{D}$, we find a robust positive direct effect of the foreign licenses on performance even without the (useful) contribution of R\&D. We believe that our results differ not only due to the alternative types of performance employed as dependent variables, but also due to the differences in timing and countries considered in the two studies. Indeed, while Tsai and Wang (2009) focus on a sample of Taiwanese firms during the period 1998-2002, our study uses a sample of Indian firms in the period 2001-2013. This means that the period considered by Tsai and Wang (2009) corresponds to a very early stage of the rise of EMFs, when most of the companies were likely to lack sufficient absorptive capacities. Conversely, we consider a different country and a longer and more recent period, during which several Indian firms have been able to develop absorptive capacities in-house, not only by hiring more skilled workers, but also through other mechanisms such as, competitive interactions, strategic alliances and joint-ventures undertaken with MNEs abroad or at home (Gaur et al. 2014; Kristinsson and Rao 2008; Kumaraswamy et al. 2012; Narayanan 1998). Indian firms are likely to have benefited from positive 
technological knowledge spillovers by interacting with foreign companies (e.g., suppliers or competitors), thus enabling them to develop their own absorptive capacity. Hence, in our context, internal R\&D still plays a crucial role in enhancing the impact of inward licensing on financial performance through the mechanisms described above; however, it is a not a necessary condition to trigger the positive effect of inward licensing.

Finally, we find that EMFs affiliated to business groups are less able to enjoy the benefits derived from foreign licensing, compared to their non-affiliated counterparts. A first explanation (in comparison to non-group affiliated firms) relies on the fact that the group affiliated firms have better endowment of resources, which marginalize the positive effect of foreign technological knowledge. Indeed, the diversity of the network resources of the business groups allows the affiliated firm to develop their own technological knowledge and competences, meaning that the contribution of the inward licenses might be more marginal, while the non-business group EMFs are likely to be more dependent on the use of foreign technological resources to boost their performance.

The other possible reason for lesser positive effect lies in the lower control on and different nature of the network resources. On the one hand, unlike internal R\&D, which is under the full control of the EMF, the network resources of the business group are owned by other firms, meaning that they do not necessarily contribute to the direct development of the absorptive capacities of the EMF that are required to understand the advanced technological knowledge embedded in the foreign inward license. On the other hand, unlike internal $R \& D$, which can be totally tailored on the technological content of the foreign inward licenses in order to maximize the synergetic effect, network resources are not necessarily fully complementary with respect to the technological knowledge provided by the inward license, thus reducing its amplifying effect.

\subsection{Managerial Implications}

As managerial implication, our findings confirm that inward licensing is an important mean for accessing foreign technological resources, which assist the firm's financial performance (Leone and Reichstein 2012; Tsai and Wang 2009; Wang et al. 2013). The extant literature on licensing suggests that foreign licensing improves the firm's efficiency and positively influences product and process innovations. It also facilitates firm's learning ability and aids the development of internal capabilities, especially in the context of technological knowledge transfer from advanced to developing economies (Katrak 1990; Pitkethly 2001).

Building on this, our results reveal that EMFs that benefit more from inward licenses are those ones performing internal $R \& D$ and not affiliated to business groups. Thus, EMF not belonging to business groups should consider acquisition of foreign licenses as a strategy to access advanced technological knowledge that can be employed to develop a competitive advantage and, hence, to increase their financial performance. Conversely, EMFs belonging to business groups should be aware that the strategy of enhancing financial performance is likely to provide a weaker (although 
still positive) effect on their financial performance. Therefore, EMFs' belonging to business groups should first explore the possibility to exploit their in-house network resources or alternative strategies to source foreign technological knowledge.

\subsection{Future Research Developments}

This paper offers opportunities for future research development. First, we analyze inward licensing as form of external technological knowledge sourcing, but future studies should explore whether and how other strategies, such as alliances and FDI, provide an effective contribution to the development of the competitive advantage of EMFs (especially those affiliated to business groups) and to the rise of their financial performance. Second, we provide evidence of the interaction effect of both R\&D and business group affiliation on the relationship between foreign technology inward licensing and financial performance. Future works might also study the impact of these contingencies on other types of performance, particularly innovation performance (in terms of patents or new products), extending the existing evidence that establishes a relation between inward licensing and innovation performance. Third, future studies could investigate the relationship between foreign licenses and financial performance by exploring the contingent effect arising from alternative sources of firm-level heterogeneity besides business group affiliation (e.g., family or state ownership), or by exploring more in depth the heterogeneity within each category (e.g., by identifying different types of business groups). Fourth, our study is embedded within the context of India. Future research may use a sample of EMFs from other countries, preferably a cross-country sample, and test whether our results are influenced by specific institutional features varying across emerging economies. Finally, due to data limitation, we were not able to disentangle the characteristics of technologies underlying EMFs' license portfolio (e.g., newness, complexity, relatedness), as well as different sources of licenses (e.g., university, private vendor, public and government laboratory). Therefore, a comprehensive study on how different characteristics and sources of technology licensing portfolio affect firm performance can govern the future research agenda.

\section{Conclusions}

Although we acknowledge that our study is affected by the idiosyncrasies of Indian firms, meaning that it may not be generalizable to the context of EMFs from other countries (Tsang and Williams 2012), we believe that it still provides relevant contributions to the literature at the intersection of international business and innovation management, which we invite future scholars to investigate also in other emerging countries' context. First, taking a KBV perspective and combining it with the RDT, we highlight both the stand-alone positive contribution of the external knowledge provided by foreign inward licenses to financial performance and the contingencies arising from the combination of externally sourced technological knowledge with the internal knowledge and resources of a firm in fostering its (knowledge-based) 
competitive advantage. Secondly, taking a complementary international business perspective of foreign licensing, which has mainly been studied using the licensor firm's point of view (e.g., Contractor 1981), we provide original theoretical and empirical contributions to the existing literature by adopting the licensee point of view. Finally, we offer new insights to the evolving literature on EMFs, which has traditionally focused on firms implementing a knowledge sourcing strategy through FDI (e.g., Contractor 1985; Kotabe et al. 1996). We provide evidence on the knowledge sourcing strategy implemented through foreign inward technology licensing and its effect on performance, as well as on the role of business groups within the Indian context.

Moreover, our study complements and updates the existing works that have either analyzed the impact of foreign technology licensing but only on innovative performance (Tsai and Wang 2009; Wang et al. 2013), or studied the impact of inward technology licensing on firm performance without arguing on the different contribution provided by the geographic origin of inward licenses (Tsai and Wang 2008). We add new insights by showing the importance of considering idiosyncratic characteristics of inward licenses, such as the country of origin, by assessing the superior impact of cross-border (with respect to domestic) technological knowledge embedded in foreign licenses on financial performance.

Finally, and most importantly, our results also provide a contribution to the empirical literature on the relationship between business groups and performance (e.g., Belenzon and Berkovitz 2010; Kedia et al. 2006). We highlight that being affiliated to a business group reduces the effectiveness of the impact of inward foreign licenses on the financial performance. We thus extend the current understanding of the KBV and RDT by suggesting that having access to network resources (i.e., the resources owned by the companies belonging to a business group) might not be sufficient to maximize the positive effects arising from the acquisition of advanced external technological knowledge through foreign inward licenses. The firm as an institution amassing knowledge may gain reduced marginal utility by adding an additional source of technological knowledge due to the availability of alternative knowledge resources within the business group. Moreover, the marginal effect of resources embedded in other firms within the group depends upon the ownership and nature of these resources, which are informed by the way in which the firm is organized and structured.

Acknowledgements The earlier version of this paper was nominated for the Best Paper award in the Academy of International Business Conference, 2016, held at New Orleans, USA, under two different categories: 1. Emerging economy research award (sponsored by Bryant University); and 2. That's Interesting! research award (Aalto University).

Open Access This article is licensed under a Creative Commons Attribution 4.0 International License, which permits use, sharing, adaptation, distribution and reproduction in any medium or format, as long as you give appropriate credit to the original author(s) and the source, provide a link to the Creative Commons licence, and indicate if changes were made. The images or other third party material in this article are included in the article's Creative Commons licence, unless indicated otherwise in a credit line to the material. If material is not included in the article's Creative Commons licence and your intended use is not permitted by statutory regulation or exceeds the permitted use, you will need to obtain permission directly from the copyright holder. To view a copy of this licence, visit http://creativecommons.org/licen ses/by/4.0/. 


\section{References}

Aggarwal, A. (2000). Deregulation, technology imports and in-house R\&D efforts: An analysis of the Indian experience. Research Policy, 29(9), 1081-1093.

Ahuja, G., \& Katila, R. (2001). Technological acquisitions and the innovation performance of acquiring firms: A longitudinal study. Strategic Management Journal, 22(3), 197-220.

Arora, A., Fosfuri, A., \& Gambardella, A. (2001). Markets for technology and their implications for corporate strategy. Industrial and Corporate Change, 10(2), 419-451.

Athreye, S., \& Cantwell, J. (2007). Creating competition?: Globalisation and the emergence of new technology producers. Research Policy, 36(2), 209-226.

Atuahene-Gima, K. (1992). Determinants of inward technology licensing intentions: An empirical analysis of Australian engineering firms. Journal of Product Innovation Management, 10(3), 230-240.

Atuahene-Gima, K. (1993). Determinants of inward technology licensing intentions: An empirical analysis of Australian engineering firms. Journal of Product Innovation Management, 10(3), 230-240.

Awate, S., Larsen, M. M., \& Mudambi, R. (2012). EMNE catch-up strategies in the wind turbine industry: Is there a trade-off between output and innovation capabilities? Global Strategy Journal, 2(3), $205-223$.

Awate, S., Larsen, M. M., \& Mudambi, R. (2015). Accessing vs. sourcing knowledge: A comparative study of R\&D internationalization between emerging and advanced economy firms. Journal of International Business Studies, 46(1), 63-86.

Baier, C., Hartmann, E., \& Moser, R. (2008). Strategic alignment and purchasing efficacy: An exploratory analysis of their impact on financial performance. Journal of Supply Chain Management, 44(4), 36-52.

Belenzon, S., \& Berkovitz, T. (2010). Innovation in business groups. Management Science, 56(3), $519-535$.

Bernard, A. B., \& Jensen, J. B. (1999). Exceptional exporter performance: Cause, effect, or both? Journal of International Economics, 47(1), 1-25.

Bernard, A. B., \& Jensen, J. B. (2004). Why some firms export. Review of Economics and Statistics, $86(2), 561-569$.

Bhaumik, S. K., Driffield, N., \& Pal, S. (2010). Does ownership structure of emerging-market firms affect their outward FDI? The case of the Indian automotive and pharmaceutical sectors. Journal of International Business Studies, 41(3), 437-450.

Buckley, P. J., Elia, S., \& Kafouros, M. (2014). Acquisitions by emerging market multinationals: Implications for firm performance. Journal of World Business, 49(4), 611-632.

Buckley, P. J., \& Munjal, S. (2017). The role of local context in the cross-border acquisitions by emerging economy multinational enterprises. British Journal of Management, 28(3), 372-389.

Buckley, P., Munjal, S., Enderwick, P., \& Forsans, N. (2016a). Do foreign resources impede or assist internationalisation? Evidence from internationalisation of Indian multinational enterprises. International Business Review, 25(1), 130-140.

Buckley, P. J., Munjal, S., Enderwick, P., \& Forsans, N. (2016b). The role of experiential and non-experiential knowledge in cross-border acquisitions: The case of Indian multinational enterprises. Journal of World Business, 51(5), 675-685.

Buckley, P. J., Munjal, S., Enderwick, P., \& Forsans, N. (2016c). Cross-border acquisitions by Indian multinationals: Asset exploitation or asset augmentation? International Business Review, 25(4), 986-996.

Businesswire. (2016). Fuel Tech Licenses SNCR Technology to India's ISGEC Heavy Engineering Ltd. Business Wire [online] http://www.businesswire.com/news/home/20160601006309/en/Fuel-TechLicenses-SNCR-Techology-India\%E2\%80\%99s-ISGEC. Assessed 18 Oct 2016.

Cantwell, J. (1989). Technological innovation and multinational corporations. Basil: Blackwell.

Carr, A. S., \& Pearson, J. N. (2002). The impact of purchasing and supplier involvement on strategic purchasing and its impact on firm's performance. International Journal of Operations \& Production Management, 22(9), 1032-1053.

Cassiman, B., \& Veugelers, R. (2006). In search of complementarity in innovation strategy: Internal R\&D and external knowledge acquisition. Management Science, 52(1), 68-82.

Chang, S. J., Chung, C. N., \& Mahmood, I. P. (2006). When and how does business group affiliation promote firm innovation? A tale of two emerging economies. Organization Science, 17(5), 637-656. 
Chang, S. J., \& Hong, J. (2000). Economic performance of group-affiliated companies in Korea: Intragroup resource sharing and internal business transactions. Academy of Management Journal, 43(3), 429-448.

Chatterji, D. (1996). Accessing external sources of technology. Research Technology Management, 39(2), 48.

Chatterji, D., \& Manuel, T. A. (1993). Benefiting from external sources of technology. Research-Technology Management, 36(6), 21-26.

Chesbrough, H. W. (2003). Open innovation: The new imperative for creating and profiting from technology. Boston: Harvard Business School Press.

Chittoor, R., Aulakh, P. S., \& Ray, S. (2015). Accumulative and assimilative learning, institutional infrastructure, and innovation orientation of developing economy firms. Global Strategy Journal, 5(2), 133-153.

Chittoor, R., Sarkar, M. B., Ray, S., \& Aulakh, P. S. (2009). Third-world copycats to emerging multinationals: Institutional changes and organizational transformation in the Indian pharmaceutical industry. Organization Science, 20(1), 187-205.

Chung, W., \& Yeaple, S. (2008). International knowledge sourcing: Evidence from US firms expanding abroad. Strategic Management Journal, 29(11), 1207-1224.

Cohen, W. M., \& Levinthal, D. A. (1990). Absorptive capacity: A new perspective on learning and innovation. Administrative Science Quarterly, 35(March), 128-152.

Colombo, M. G., Croce, A., \& Murtinu, S. (2014). Ownership structure, horizontal agency costs and the performance of high-tech entrepreneurial firms. Small Business Economics, 42(2), 265-282.

Contractor, F. J. (1981). The role of the licensing in international strategy. Columbia Journal of World Business, 16(4), 73-83.

Contractor, F. J. (1985). Licensing in international strategy: A guide for planning and negotiations. Westport: Quorum Books.

Cuervo-Cazurra, A., \& Genc, M. (2008). Transforming disadvantages into advantages: Developingcountry MNEs in the least developed countries. Journal of International Business Studies, 39(6), 957-979.

Cui, L., Fan, D., Liu, X., \& Li, Y. (2016). Where to seek strategic assets for competitive catch-up? A configurational study of emerging multinational enterprises expanding into foreign strategic factor markets. Organization Studies, 38(8), 1059-1083.

DeCarolis, D., \& Deeds, D. (1999). The impact of stocks and flows of organizational knowledge on firm performance: An empirical investigation of the biotechnology industry. Strategic Management Journal, 20(10), 953-968.

Deeds, D. L., \& Hill, C. W. (1996). Strategic alliances and the rate of new product development: An empirical study of entrepreneurial biotechnology firms. Journal of Business Venturing, 11(1), 41-55.

Deng, P. (2009). Why do Chinese firms tend to acquire strategic assets in international expansion? Journal of World Business, 44(1), 74-84.

Doh, J. P., Lawton, T. C., Rajwani, T., \& Paroutis, S. (2014). Why your company may need a chief external officer. Organizational Dynamics, 43(2), 96-104.

Duysters, G., Jacob, J., Lemmens, C., \& Jintian, Y. (2009). Internationalization and technological catching up of emerging multinationals: A comparative case study of China's Haier group. Industrial and Corporate Change, 18(2), 325-349.

Eisenhardt, K. M., \& Santos, F. M. (2002). Knowledge-based view: A new theory of strategy. In A. Pettigrew, et al. (Eds.), Handbook of strategy and management (1st ed., pp. 139-164). Thousand Oaks: Sage Publications.

Felin, T., \& Hesterly, W. S. (2007). The knowledge-based view, nested heterogeneity, and new value creation: Philosophical considerations on the locus of knowledge. Academy of Management Review, 32(1), 195-218.

Fey, C. F., \& Birkinshaw, J. (2005). External sources of knowledge, governance mode, and R\&D performance. Journal of Management, 31(4), 597-621.

Frishammar, J., Lichtenthaler, U., \& Rundquist, J. (2012). Identifying technology commercialization opportunities: The importance of integrating product development knowledge. Journal of Product Innovation Management, 29(4), 573-589.

Fu, X., Pietrobelli, C., \& Soete, L. (2011). The role of foreign technology and indigenous innovation in the emerging economies: Technological change and catching-up. World Development, 39(7), 1204-1212. 
Galunic, D. C., \& Eisenhardt, K. M. (1994). Renewing the strategy-structure-performance paradigm. In L. L. Cummings \& B. M. Staw (Eds.), Research in organizational behavior (pp. 215-255). Greenwich: Jai Press.

Gaur, A. S., Kumar, V., \& Singh, D. (2014). Institutions, resources, and internationalization of emerging economy firms. Journal of World Business, 49(1), 12-20.

Govindarajan, V., \& Ramamurti, R. (2011). Reverse innovation, emerging markets, and global strategy. Global Strategy Journal, 1(3-4), 191-205.

Grant, R. M. (1991). The resource-based theory of competitive advantage: Implications for strategy formulation. California Management Review, 33(3), 114-135.

Grant, R. M. (1996). Toward a knowledge-based theory of a firm. Strategic Management Journal, 17(S2), $109-122$.

Green, W. H. (1997). Econometric analysis (3rd ed.). Upper Saddle River: Prentice-Hall.

Grilli, L., \& Murtinu, S. (2015). New technology-based firms in Europe: Market penetration, public venture capital, and timing of investment. Industrial and Corporate Change, 24(5), 1109-1148.

Gubbi, S. R., Aulakh, P. S., Ray, S., Sarkar, M. B., \& Chittoor, R. (2010). Do international acquisitions by emerging-economy firms create shareholder value? The case of Indian firms. Journal of International Business Studies, 41(3), 397-418.

Gulati, R. (1998). Alliances and networks. Strategic Management Journal, 19(4), 293-317.

Howells, J., James, A., \& Malik, K. (2003). The sourcing of technological knowledge: Distributed innovation processes and dynamic change. $R \& D$ Management, 33(4), 395-409.

Hsieh, W. L., Ganotakis, P., Kafouros, M., \& Wang, C. (2018). Foreign and domestic collaboration, product innovation novelty, and firm growth. Journal of Product Innovation Management, 35(4), $652-672$.

Kafouros, M. I., \& Forsans, N. (2012). The role of open innovation in emerging economies: Do companies profit from the scientific knowledge of others? Journal of World Business, 47(3), 362-370.

Katrak, H. (1990). Imports of technology and the technological effort of Indian enterprises. World Development, 18(3), 371-381.

Kedia, B. L., Mukherjee, D., \& Lahiri, S. (2006). Indian business groups: Evolution and transformation. Asia Pacific Journal of Management, 23(4), 559-577.

Kessler, E. H., Bierly, P. E., \& Gopalakrishnan, S. (2000). Internal vs. external learning in new product development: Effects on speed, costs and competitive advantage. $R \& D$ Management, 30(3), 213-224.

Khanna, T., \& Rivkin, J. W. (2001). Estimating the performance effects of business groups in emerging markets. Strategic Management Journal, 22(1), 45-74.

Kogut, B., \& Zander, U. (1992). Knowledge of the firm, combinative capabilities, and the replication of technology. Organization Science, 3(3), 383-397.

Kotabe, M., Sahay, A., \& Aulakh, P. S. (1996). Emerging role of technology licensing in the development of global product strategy: Conceptual framework and research propositions. Journal of Marketing, 60(1), 73-88.

Kristinsson, K., \& Rao, R. (2008). Interactive learning or technology transfer as a way to catch-up? Analysing the wind energy industry in Denmark and India. Industry and Innovation, 15(3), 297-320.

Kumaraswamy, A., Mudambi, R., Saranga, H., \& Tripathy, A. (2012). Catch-up strategies in the Indian auto components industry: Domestic firms' responses to market liberalization. Journal of International Business Studies, 43(4), 368-395.

Lall, S. (2000). Technological change and industrialization in the Asian newly industrializing economies: Achievements and challenges. In K. Linsu \& R. R. Nelson (Eds.), Technology, learning, \& innovation: Experiences of newly industrializing economies (pp. 13-68). Cambridge: Cambridge University Press.

Lall, S. (2003). Foreign direct investment, technology development and competitiveness: Issues and evidence. In S. Lall \& S. Urata (Eds.), Competitiveness, FDI and technological activity in East Asia. Association with the World Bank. Cheltenham: Edward Elgar.

Leone, M. I., \& Reichstein, T. (2012). Licensing-in fosters rapid invention! The effect of the grant-back clause and technological unfamiliarity. Strategic Management Journal, 33(8), 965-985.

Levin, D. Z., \& Barnard, H. (2013). Connections to distant knowledge: Interpersonal ties between moreand less-developed countries. Journal of International Business Studies, 44(7), 676-698.

Levinthal, D. A., \& March, J. G. (1993). The myopia of learning. Strategic Management Journal, 14(S2), 95-112. 
Liu, X., Hodgkinson, I. R., \& Chuang, F. M. (2014). Foreign competition, domestic knowledge base and innovation activities: Evidence from Chinese high-tech industries. Research Policy, 43(2), 414-422.

Liu, X., \& Zou, H. (2008). The impact of greenfield FDI and mergers and acquisitions on innovation in Chinese high-tech industries. Journal of World Business, 43(3), 352-364.

London, T., \& Hart, S. L. (2004). Reinventing strategies for emerging markets: Beyond the transnational model. Journal of International Business Studies, 35(5), 350-370.

Luo, Y., \& Tung, R. L. (2007). International expansion of emerging market enterprises: A springboard perspective. Journal of International Business Studies, 38(4), 481-498.

Maddala, G. S. (1993). Introduction. In G. S. Maddala (Ed.), The econometrics of panel data (p. XIXXI). Aldershot: Elgar.

Malik, O. R., \& Kotabe, M. (2009). Dynamic capabilities, government policies, and performance in firms from emerging economies: Evidence from India and Pakistan. Journal of Management Studies, 46(3), 421-450.

McGrath, R. G., Tsai, M., Venkataraman, S., \& MacMillan, I. C. (1996). Innovation, competitive advantage, and rent. Management Science, 42(3), 389-403.

Miller, J. D., Fern, M. J., \& Cardinal, L. B. (2007). The use of knowledge for technological innovation within diversified firms. Academy of Management Journal, 50(2), 308-326.

Minagawa, T., Trott, P., \& Hoecht, A. (2007). Counterfeit, imitation, reverse engineering and learning: Reflections from Chinese manufacturing firms. $R \& D$ Management, 37(5), 455-467.

Mowery, D. C. (1988). International collaborative ventures in U.S. manufacturing. Cambridge: Ballinger.

Munjal, S., Buckley, P. J., Enderwick, P., \& Forsans, N. (2013). The growth trajectory of Indian MNEs. In C. Brautaset \& C. Dent (Eds.), The great diversity-trajectories of Asian development. Wageningen: Wageningen Academic Press.

Munjal, S., Requejo, I., \& Kundu, S. K. (2019). Offshore outsourcing and firm performance: Moderating effects of size, growth and slack resources. Journal of Business Research, 103(C), 484-494.

Narayanan, K. (1998). Technology acquisition, de-regulation and competitiveness: A study of Indian automobile industry. Research Policy, 27(2), 215-228.

Oura, H., Hume, A. R., Papi, L., Saxegaard, M., Petia, T., Peiris, S. J., et al. (2009). India: Selected issues. Washington, D.C: International Monetary Fund.

Pavlínek, P. (2018). Global production networks, foreign direct investment, and supplier linkages in the integrated peripheries of the automotive industry. Economic Geography, 94(2), 141-165.

Pereira, V., Munjal, S., \& Ishizaka, A. (2019). Outsourcing and offshoring decision making and its implications for businesses-A synthesis of research pursuing five pertinent questions. Journal of Business Research, 103, 348-355.

Perri, A., Scalera, V. G., \& Mudambi, R. (2016). What are the most promising conduits for foreign knowledge inflows? Innovation networks in the Chinese Pharmaceutical Industry. Industrial and Corporate Change, 26(2), 333-355.

Petersen, M. A. (2009). Estimating standard errors in finance panel data sets: Comparing approaches. Review of Financial Studies, 22(1), 435-480.

Pfeffer, J., \& Salancik, G. (1978). The external control of organizations: A resource-dependence perspective. New York: Harper \& Row.

Pitkethly, R. H. (2001). Intellectual property strategy in Japanese and UK companies: Patent licensing decisions and learning opportunities. Research Policy, 30(3), 425-442.

Roberts, P. W., \& Dowling, G. R. (2002). Corporate reputation and sustained superior financial performance. Strategic Management Journal, 23(12), 1077-1093.

Sapienza, H. J., De Clercq, D., \& Sandberg, W. R. (2005). Antecedents of international and domestic learning effort. Journal of Business Venturing, 20(4), 437-457.

Scalera, V. G., Mukherjee, D., \& Piscitello, L. (2020). Ownership strategies in knowledge-intensive cross-border acquisitions: Comparing Chinese and Indian MNEs. Asia Pacific Journal of Management, 37(1), 155-185.

Scalera, V. G., Perri, A., \& Hannigan, T. J. (2018). Knowledge connectedness within and across home country borders: Spatial heterogeneity and the technological scope of firm innovations. Journal of International Business Studies, 49(8), 990-1009.

Semykina, A., \& Wooldridge, J. M. (2010). Estimating panel data models in the presence of endogeneity and selection. Journal of Econometrics, 157(2), 375-380. 
Sikimic, U., Chiesa, V., Frattini, F., \& Scalera, V. G. (2016). Investigating the influence of technology inflows on technology outflows in open innovation processes: A longitudinal analysis. Journal of Product Innovation Management, 33(6), 652-669.

Spear, S. J. (2009). Chasing the rabbit: How market leaders outdistance the competition and how great companies can catch up and win. New York: McGraw-Hill.

Spencer, J. W. (2003). Firms' knowledge-sharing strategies in the global innovation system: empirical evidence from the flat panel display industry. Strategic Management Journal, 24(3), 217-233.

Steensma, H. K., Marino, L., Weaver, K. M., \& Dickson, P. H. (2000). The influence of national culture on the formation of technology alliances by entrepreneurial firms. Academy of Management Journal, 43(5), 951-973.

Stucchi, T., Pedersen, T., \& Kumar, V. (2015). The effect of institutional evolution on Indian firms' internationalization: Disentangling inward-and outward-oriented effects. Long Range Planning, 48(5), 346-359.

Thite, M., Wilkinson, A., Budhwar, P., \& Mathews, J. A. (2016). Internationalization of emerging Indian multinationals: Linkage, leverage and learning (LLL) perspective. International Business Review, 25(1), 435-443.

Tidd, J., Pavitt, K., \& Bessant, J. (2001). Managing innovation. Chichester: Wiley.

Tsai, K. H., \& Wang, J. C. (2008). External technology acquisition and firm performance: A longitudinal study. Journal of Business Venturing, 23(1), 91-112.

Tsai, K. H., \& Wang, J. C. (2009). External technology sourcing and innovation performance in LMT sectors: An analysis based on the Taiwanese Technological Innovation Survey. Research Policy, 38(3), 518-526.

Tsang, E. W. K., \& Williams, J. N. (2012). Generalization and induction: Misconceptions, clarifications, and a classification of induction. MIS Quarterly, 36(3), 729-748.

van de Vrande, V., Vanhaverbeke, W., \& Duysters, G. (2011). Technology in-sourcing and the creation of pioneering technologies. Journal of Product Innovation Management, 28(6), 974-987.

von Zedtwitz, M., Corsi, S., Søberg, P. V., \& Frega, R. (2015). A typology of reverse innovation. Journal of Product Innovation Management, 32(1), 12-28.

Wang, Y., Roijakkers, N., \& Vanhaverbeke, W. (2013). Learning-by-licensing: How Chinese firms benefit from licensing-in technologies. IEEE Transactions on Engineering Management, 60(1), 46-58.

Winter, S. G., \& Szulanski, G. (2001). Replication as strategy. Organization Science, 12(6), 730-743.

Young, S., Huang, C. H., \& McDermott, M. (1996). Internationalization and competitive catch-up processes: Case study evidence on Chinese multinational enterprises. Management International Review, 36(4), 295-314.

Zelner, B. A. (2009). Using simulation to interpret results from logit, probit, and other nonlinear models. Strategic Management Journal, 30(12), 1335-1348.

Publisher's Note Springer Nature remains neutral with regard to jurisdictional claims in published maps and institutional affiliations. 